\title{
Organoleptic Properties of Food Products from Tempe Lake Fish
}

\author{
Darwis $^{1}$, Muhammad Ardi $^{2}$ and Nurlita Pertiwi ${ }^{3}$ \\ ${ }^{1}$ Universitas Puangrimaggalatung \\ Sengkang, South Sulawesi, Indonesia \\ Email: darwisalqadri12 [AT] gmail.com \\ ${ }^{2}$ Universitas Negeri Makassar \\ Makassar, South Sulawesi, Indonesia \\ Email: muhammadardi [AT] unm.ac.id \\ ${ }^{3}$ Universitas Negeri Makassar \\ Makassar, South Sulawesi, Indonesia \\ Email: nurlita.pertiwi [AT] unm.ac.id
}

\begin{abstract}
The potential freshwater fish of Lake Tempe has long been consumed by the local community. However, its use is minimal. This article describes the organoleptic properties of fish cakes and fish floss as the development of various forms of food made from fish of Tempe Lake. The types of fish used as essential ingredients are Channa Striata and Monopterus Albus. The organoleptic test involved 70 panelists from the Department of Agricultural Technology, Universitas Negeri Makassar. Panelists assessed the color, taste, smell, and texture of the two food products. This result of the study describes the results of the organoleptic test with a comparison figure and t-test. Organoleptic test results showed that the panelists preferred the fish floss from Channa Striata for color, smell, and taste compared to fish floss from Monopterus Albus. Panelists' assessment of the fish cake from Channa Striata was better on smell and texture, while Monopterus Albus was preferred on the color and taste test. The T-test results showed that the panelists assessments for fish cakes from Channa Striata and Monopterus Albus were similar. However, the organoleptic characteristics of fish cake are different between two kinds of lake fish.
\end{abstract}

Keywords- Fish floss, fish cake, color, texture, smell and taste

\section{INTRODUCTION}

With an area of $350 \mathrm{~km}^{2}$ in the Wajo Regency, Lake Tempe has various potentials, such as the potential of fisheries or freshwater biota. The existence of Tempe Lake as a marine fishery resource has its peculiarities. This lake has developed into a habitat for freshwater fish. During the '90s, increased 79 species of fish species[1].

The types of freshwater fish, such as goldfish, Tilapia fish, whiskers, catfish, and various other types of lake fish, have a distinctive taste than other places. The delicious taste of Lake Tempe fish has been famous in multiple places. The existence plankton community at the bottom of the lake as the primary source of fish food has provided high taste and nutritional value[2]. Snakehead fish or (Channa Striata) is a type of predatory fish that lives in Tempe lake, well known by the public. The fish has a low taste and is less favorable. Although several studies have written that this type of fish has a high albumin content and good for health. Also, this type of fish has a high protein content or as a source of nutritious food [3]

Swamp eel (Monopterus Albus) is the other kind of fish in Tempe Lake. This fish is alive because it can breathe in the air. Even this type of fish can survive without food, making it possible to transport long distances. Several references state that the Swamp Eel can live in tight packs as long as conditions are humid [4]. Swamp eel is a protein source species with high nutritional value. Also, this type of fish has the benefits of treating various diseases [5]. On the shores of Lake Tempe, people buy this fish in traditional markets using two methods, buying this fish after being slaughtered or bringing it home alive. This fish is available in the local trade all year round.

The community processes snakehead fish and Swamp eels in traditional ways; however, the food product is less attractive to children. The potential of these two types of fish as a source of healthy food for children is enormous. Therefore, the researchers introduced other processing methods so that the fish was in demand by children. Fish floss can be made from snakehead fish and Swamp eel after first being finely shredded and mixed with local spices (garlic, shallot, and pepper). The ingredients are then fried until cooked and then drained to remove the oil content. 
Meanwhile, the fish cake is a food that is shaped like a cake with a soft texture and white color. The fish meat is mashed first; then, it is mixed with tapioca flour, coconut milk, eggs, and local spices. The primary ingredient dough is printed in a square shape and then wrapped in banana leaves. The cooking process is by steaming for 15-30 minutes. Foodstuffs are durable with storage at a temperature of $10-18^{\circ} \mathrm{C}$.

Organoleptic test as an evaluation of consumer appetite for a new food product. The method can also serve as a guide for business development and product marketing. As judges of taste and other characteristics, panelists must have experience and knowledge of the sense principles and influencing factors. Also, panelists must be able to detect and distinguish certain characteristics (specific characteristics) of foodstuffs. Therefore, the panelists' assessment results can serve as a reference regarding the nature of food.

\section{METHODS}

This type of research is survey research to assess fish cake and fish floss made from Snakehead fish and Swamp Eel. Researchers tested organoleptic properties to find panelists' perceptions of color, taste, aroma, and texture. Panelists give a numerical rating from 1 to 5 . A score of 1 means they don't like it, and 5 means they like it.

Seventy panelists are final year students in the Department of Agricultural Technology Education, Makassar State University. All panelists have passed the sensing test and tasting recognition in the laboratory. The method used is by asking the panelists to give an assessment based on color, taste, aroma, and texture (organoleptic test). The panelists' average result is divided into three categories: like, somewhat like, and dislike. The data that has been obtained is analyzed descriptively, then testing the difference in the average value of the panelists using the T-test method.

\section{RESULTS}

\subsection{Organoleptic Results}

Organoleptic Test of Fish floss from Snakehead fish and Swamp Eel

fish floss from swamp eel based on color

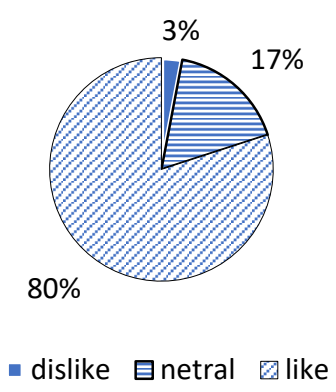

fish floss from snakehead fish based on color

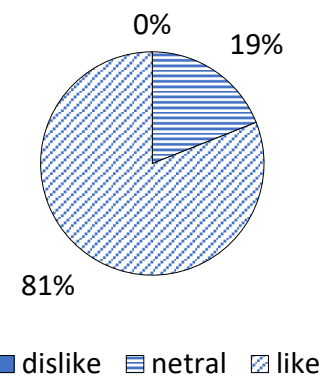

Figure 1: Organoleptic test of Fish floss from Snakehead fish and Swamp Eel based on color

Based on figure 1. the results of the frequency test on the panelists' assessment show that the color of Fish floss from snakehead fish and swamp eel is preferred, or these two food products show attractive colors. The shade of Fish floss from snakehead fish brighter than the color of fish floss from Swamp. Eel. The difference in color between the two foodstuffs is due to the water content in the essential ingredients of fish floss from Swamp eel, which contains more water. The frying process takes longer and causes a slightly darker color. Furthermore, the taste qualities of the two types of Shredded are presented in figure 2 . 
fish floss from swamp eel based on taste

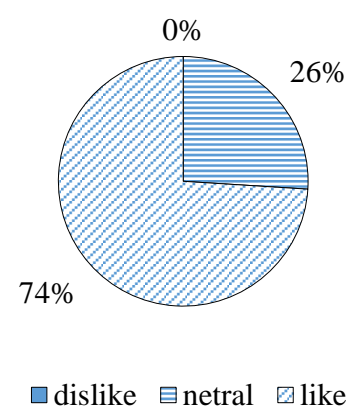

fish floss from snakehead fish based on taste

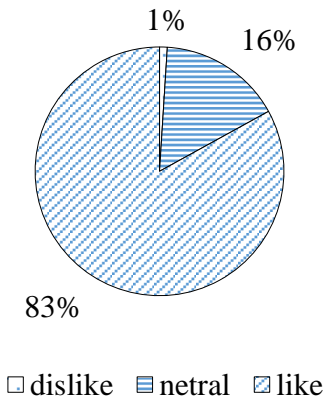

Figure 2: Organoleptic test of Fish floss from Snakehead fish and Swamp Eel based on taste

Based on figure 2. The frequency test results show that the panelists like Fish floss from snakehead fish and fish floss from swamp eel. They have a savory taste because they contain glutamic acid. The taste assessment is due to the longer frying process of Swamp Eel, which causes a change in the flavor of the marinade.

The smell of food is a determining factor for consumer attractiveness. The smell comes from the addition of spices or seasonings to the mixing process. Organoleptic test results are presented in figure 3.
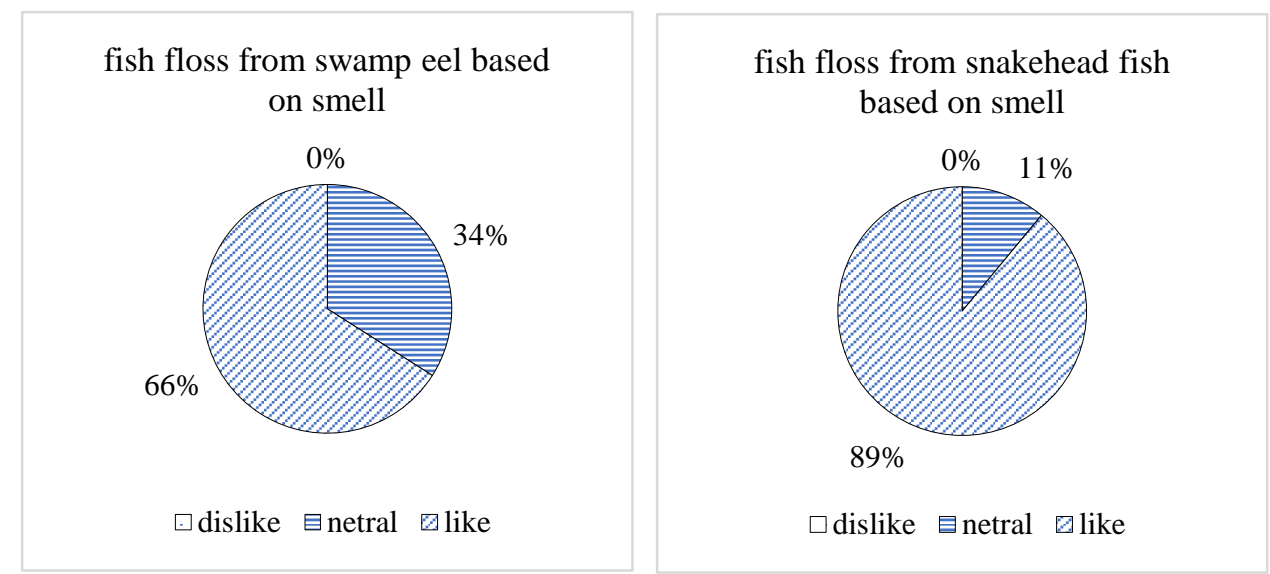

Figure 3: Organoleptic test of Fish floss from Snakehead fish and Swamp Eel based on smell

Based on figure 3. The results of the panelists' assessment of the smell of Fish floss from Snakehead and fish floss from Swamp eel show that the smell of Fish floss from Snakehead is more attractive compared to fish floss from Swamp eel. This is because there is a distinctive fish smell of fish floss from Swamp eel. Texture has an essential role in organoleptic tests. The surface is closely related to the sense of taste during the process of consumption in the mouth. The texture test can be seen in figure 4 . 
fish floss from swamp eel based on texture

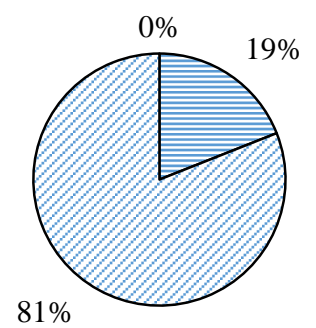

$\square$ dislike $\boxminus$ netral $\square$ like fish floss from snakehead fish based on texture

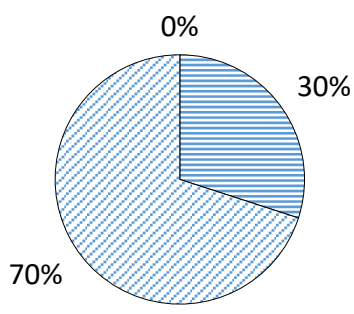

$\square$ dislike $\boxminus$ netral $\square$ like

Figure 4: Organoleptic test of Fish floss from Snakehead fish and Swamp Eel based on texture

Based on figure 4. Panelists' assessment shows that the Fish floss from swamp eel texture is more popular due to the more extended frying resulting in the Fish floss from swamp eel texture being crisper compared to the Fish floss surface. Snakehead fish.

\section{Organoleptic Test of Fish cake from Snakehead fish and Swamp Eel}

Otak Otak (fish cake) is white due to the addition of flour and coconut milk during the manufacturing process. The results of the color quality test based on the organoleptic test are presented in figure 5.

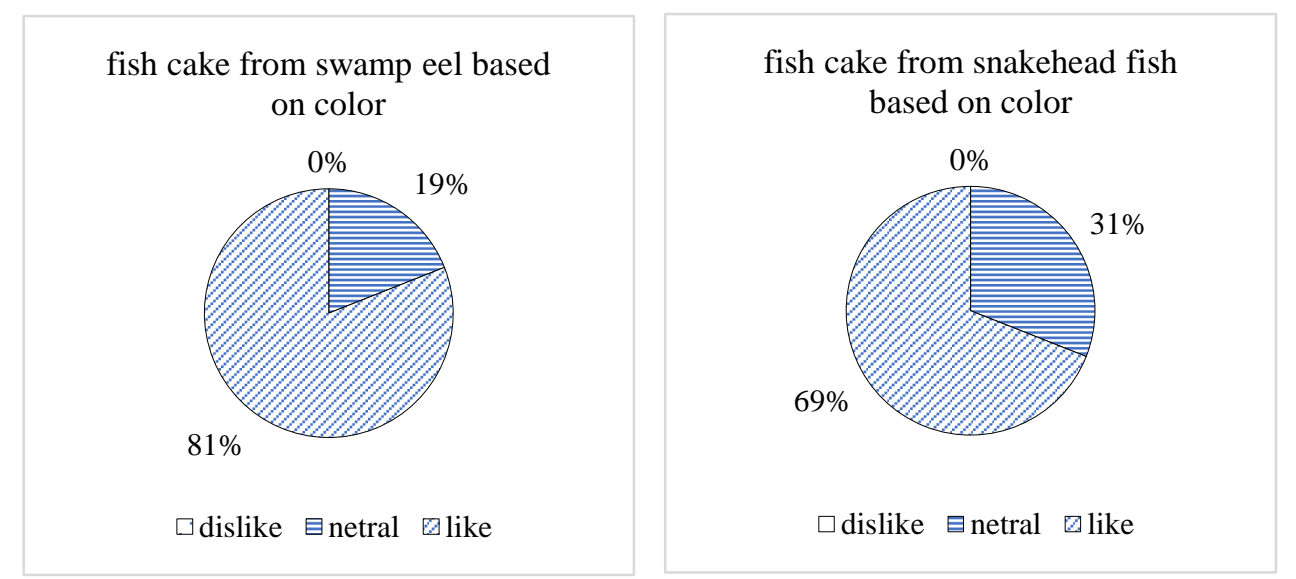

Figure 5: Organoleptic test of Fish cake from Snakehead fish and Swamp Eel based on color

Panelists generally prefer the color of Fish cake from swamp eel compared to Fish cake from snakehead fish. The snakehead fish produces a paler color compared to the Swamp Eel. As a result, the Fish cake from snakehead fish shows a less attractive color. Fish Cake has a chewy and savory taste due to the addition of spices to the manufacturing processthe results of the assessment of the taste presented in figure 6. 
fish cake from swamp eel based on taste

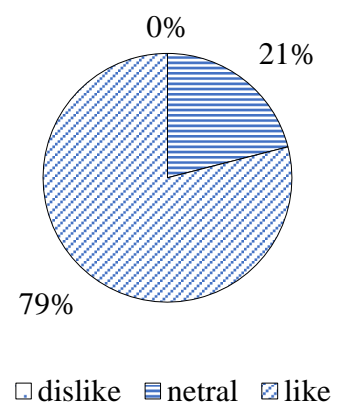

fish cake from snakehead fish based on taste

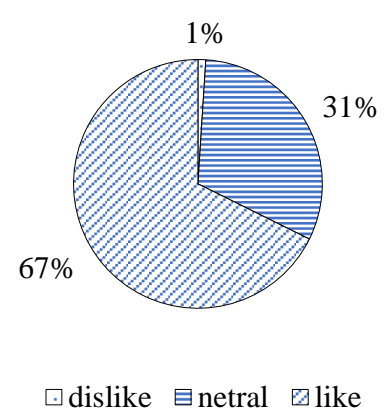

Figure 6. Organoleptic test of Fish cake from Snakehead fish and Swamp Eel based on taste

Figure 6. This shows that the panelists rated the fish cake from swamp eel as having a higher taste value. The difference in the taste of the two foods is due to differences in fat and protein content. The swamp eel contains more fat and protein compared to the snakehead fish. The properties of the basic ingredients did not change after steam. The smell of the fish cake comes from the aroma of fish and the mixture of spices. The panelists' test results on the smell quality of the ingredients are presented in figure 7 .

fish cake from swamp eel based on smell

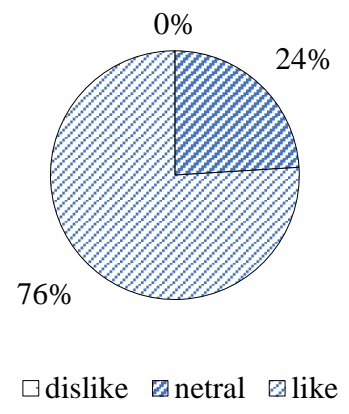

fish cake from snakehead fish based on smell

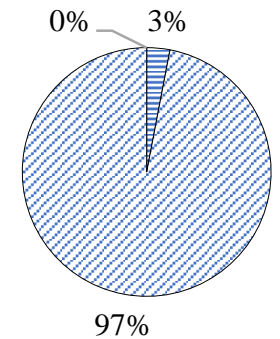

$\square$ dislike 目netral $ه$ like

Figure 7. Organoleptic test of Fish cake from Snakehead fish and Swamp Eel based on smell

Figure 7 shows that panelists prefer the smell of Fish cake from snakehead fish compared to Fish cake from swamp eel. The spice composition of the two types of dishes caused the difference in the smell. It comes from the aroma of the essential ingredients of the fish. Swamp eel has a fishier taste compared to snakehead fish, and the scent is still felt in processed food Fish cake from swamp eel Texture. Fish cake is smooth and looks shiny due to steaming. The panelist test results on the texture are presented in figure 8

fish cake from swamp eel based on texture

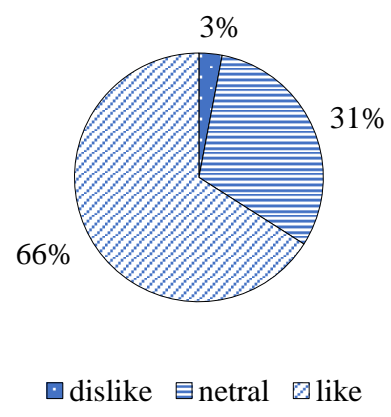

fish cake from snakehead fish based on texture

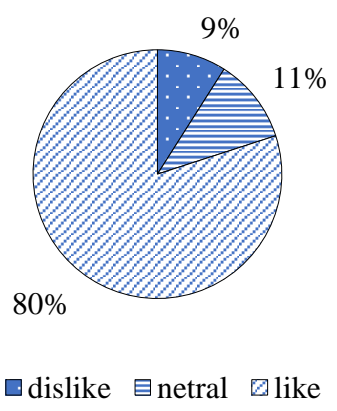

Figure 8. Organoleptic test of Fish cake from Snakehead fish and Swamp Eel based on texture 
Panelists prefer the texture of the Fish cake from snakehead fish because of its smooth nature. Meanwhile, Fish cake from swamp eel produces a slightly coarse texture because the fiber is more difficult to mash.

\subsection{The difference in organoleptic test results on the two food products}

The different test for the two food products is based on the average results of the four indicators assessed. The results of statistical analysis showed a difference.

Table 1. Different tests of Fish cake from snakehead fish and Fish cake from swamp eel

\begin{tabular}{|c|c|c|c|c|c|c|c|c|c|c|}
\hline \multicolumn{11}{|c|}{ Independent Samples Test } \\
\hline & & \multicolumn{2}{|c|}{$\begin{array}{c}\text { Levene's Test for } \\
\text { Equality of Variances }\end{array}$} & \multicolumn{7}{|c|}{ t-test for Equality of Means } \\
\hline & & \multirow[t]{2}{*}{$\mathrm{F}$} & \multirow{2}{*}{ Sig. } & \multirow{2}{*}{$\mathrm{t}$} & \multirow{2}{*}{ df } & \multirow{2}{*}{$\begin{array}{l}\text { Sig. }(2- \\
\text { tailed) }\end{array}$} & \multirow{2}{*}{$\begin{array}{c}\text { Mean } \\
\text { Difference }\end{array}$} & \multirow{2}{*}{$\begin{array}{l}\text { Std. Error } \\
\text { Difference }\end{array}$} & \multicolumn{2}{|c|}{$\begin{array}{c}95 \% \text { Confidence Interval } \\
\text { of the Difference }\end{array}$} \\
\hline & & & & & & & & & Lower & Upper \\
\hline $\begin{array}{l}\text { Organoleptic of } \\
\text { fish cake }\end{array}$ & $\begin{array}{c}\text { Equal } \\
\text { variances } \\
\text { assumed } \\
\text { Equal } \\
\text { variances not } \\
\text { assumed }\end{array}$ & 15.917 & .000 & $\begin{array}{l}-1.526 \\
-1.526\end{array}$ & 138 & .129 & -.114 & .075 & -.262 & .034 \\
\hline
\end{tabular}

Table 1 is an analysis of the independent sample T-test. Based on the 2-way (t-tailed) significance value, namely 0.129 $<0.05$, there is no significant difference in point scores between Fish cake from swamp eel and fish cake from snakehead fish.

Table 2. Different tests of Fish floss from snakehead fish and fish floss from swamp eel

\begin{tabular}{|c|c|c|c|c|c|c|c|c|c|c|}
\hline \multicolumn{11}{|c|}{ Independent Samples Test } \\
\hline & & \multicolumn{2}{|c|}{$\begin{array}{c}\text { Levene's Test for } \\
\text { Equality of } \\
\text { Variances } \\
\end{array}$} & \multicolumn{7}{|c|}{ t-test for Equality of Means } \\
\hline & & \multirow[t]{2}{*}{$\mathrm{F}$} & \multirow{2}{*}{ Sig. } & \multirow{2}{*}{$\mathrm{t}$} & \multirow{2}{*}{ df } & \multirow{2}{*}{$\begin{array}{l}\text { Sig. }(2- \\
\text { tailed) }\end{array}$} & \multirow{2}{*}{$\begin{array}{c}\text { Mean } \\
\text { Difference }\end{array}$} & \multirow{2}{*}{$\begin{array}{l}\text { Std. Error } \\
\text { Difference }\end{array}$} & \multicolumn{2}{|c|}{$\begin{array}{l}95 \% \text { Confidence Interval } \\
\text { of the Difference }\end{array}$} \\
\hline & & & & & & & & & Lower & Upper \\
\hline $\begin{array}{l}\text { Organoleptic of } \\
\text { fish floss }\end{array}$ & $\begin{array}{c}\text { Equal } \\
\text { variances } \\
\text { assumed } \\
\text { Equal } \\
\text { variances not } \\
\text { assumed }\end{array}$ & 1.485 & .225 & $\begin{array}{l}-2.754 \\
-2.754\end{array}$ & $\begin{array}{c}138 \\
136.540\end{array}$ & .007 & $\begin{array}{l}-.22571 \\
-.22571\end{array}$ & .08196 & $\begin{array}{l}-.38777 \\
-.38778\end{array}$ & -.06366 \\
\hline
\end{tabular}

Table 2 is an analysis of the independent sample t-test. The 2 -way (t-tailed) significance value is $0.007<0.05$, indicating a significant difference in point scores between Fish floss from swamp eel and Fish floss from snakehead fish. The difference is due to the organoleptic test results of Fish floss from swamp eel based on smell and texture less preferred by panelists than Fish floss from snakehead fish.

\section{DISCUSSION}

Organoleptic test results on food from snakehead fish illustrate that the unpleasant odor of fresh fish is lost due to the cooking process and the mixing of the spices. In making fish floss, the frying process uses the deep-frying method. This process uses a lot of oil, resulting in an oxidation process or the formation of fatty acid hydroperoxides. Changes in chemical composition can cause changes in the taste of food. The shredded frying process also affects water loss in food [6][7]. Effects of cooking oils and packaging media on the quality of meat floss). The community prefers this type of food because of its ease of serving. Shredded is ready-to-eat food with long durability. The process of releasing the oil after frying will produce a long-lasting shredded [8]. 
Fish cake made from fish with tapioca flour causes a change in the texture of the essential ingredients. The flour is used as a filler and binder for water in the dough. The binding process between the flour and fish causes the texture to get better, and the dough is easy to form. Therefore, the panelists liked the soft fish floss texture.

\section{CONCLUSION}

Fish floss from snakehead fish food products is preferable to fish floss from swamp eel. The advantages of floss from Snakehead are color, aroma, and taste. Meanwhile, fish cake products from snakehead fish and swamp ell ingredients are generally equally preferred. Snakehead's fish cake is better in aroma and texture, while fish cake from swamped is preferable in color and taste tests.

\section{REFERENCES}

[1] H. Haerunnisa, B. Budimawan, S. Alam Ali, and A. I. Burhanuddin, "Management Model of Sustainability Fisheries at Lake Tempe, South Sulawesi, Indonesian," Int. J. Sci. Res., vol. 4, no. 5, pp. 2319-7064, 2015.

[2] M. Hatta, N. A. Umar, S. Mulyani, and I. Suryani, "Study food habits of fishes in Tempe Lake," Int. J. Environ. Agric. Biotechnol., vol. 4, no. 4, pp. 1217-1222, 2019.

[3] A. M. Hariati, A. Yuniarti, W. E. Kusuma, and D. G. R. Wiadnya, "Albumin and enzyme profiles of dwarf snakehead, Channa gachua caught from River Brantas, East Java," in Journal of Physics: Conference Series, 2019, vol. 1146 , no. 1 , p. 12041.

[4] E. Been and L. Kalichman, "Lumbar lordosis," Spine J., vol. 14, no. 1, pp. 87-97, 2014.

[5] N. R. A. Halim, H. M. Yusof, and N. M. Sarbon, "Functional and bioactive properties of fish protein hydolysates and peptides: A comprehensive review," Trends Food Sci. Technol., vol. 51, pp. 24-33, 2016.

[6] A. Bognar, "Comparative study of frying to other cooking techniques influence on the nutritive value," Grasas $y$ Aceites, vol. 49, no. 3-4, pp. 250-260, 1998.

[7] M. Xiao, F. L. Cooke, J. Xu, and H. Bian, "To what extent is corporate social responsibility part of human resource management in the Chinese context? A review of literature and future research directions," Hum. Resour. Manag. Rev., vol. 30, no. 4, p. 100726, 2020.

[8] R. Romadhon, U. Amalia, and A. D. Anggo, "Quality Improvement of Catfish Floss (Clarias gariepinus) Through Oil Reduction Technology with Spinner and Press Tools,” Omni-Akuatika, vol. 15, no. 2, pp. 36-42, 2019. 